\title{
Corporate Governance for the Best Financing Choices: An Empirical Study from Family Firms in Northern Cameroon
}

\author{
Ake Boubakari (corresponding author) \\ Shanghai University of Finance and Economics \\ PO. BOX 200083 Shanghai-China \\ E-mail: boubakariake@yahoo.fr \\ Jules Roger Feudjo \\ Professor, Ngaoundere University \\ PO. BOX 454 Ngaoundere, Cameroon
}

\begin{abstract}
In this paper we are studying the composition of the board of directors, and its influence on the financing choices of family firms in Northern Cameroon. We provide systematic evidence that the composition of the Board of managers affects company's decision toward the presence of family members and independent administrators when an important decision should be taken for the future of the company. Based on our results, we found that the composition of the Board of Directors has a significant influence on the financing choices of family firms. For example, the presence of independent directors in the Board of Directors has a significant influence on the capital structure of the family firms.
\end{abstract}

Keywords: Family Firms, Corporate Governance, Board of Directors, Capital Structure

\section{Introduction}

With the series of mismanagements that occurred in Europe and America (cases of Enron, WorldCom, Vivendi, etc.), the corporate governance and the problem of finance got more consideration from researchers. Zaff (2000) said that the corporate governance became a field of study in expansion.

We know that corporate governance's purpose is primarily to solve the conflict of interest between shareholders and managers, by controlling the way managers run the company. A question that usually arises is in the case of family firm is: what happens since the owner and the manager are the same person? Where is the need of corporate governance when you own and manage your own company?

To answer to this question we can refer to Jensen and Meckling (1976) who said that in the days when companies were owned and run by the same person or family, there were no conflicts of interest between what the owner wanted to achieve and what the manager was trying to achieve. It is one and the same person, so clearly one objective and hence there is no problem. However, as owners and managers became separate, problems of agency arose. The only way to deal with this problem effectively is through good corporate governance's mechanism.

We understand that the main reason of corporate governances' existence is that managers do not always act in the best interest of shareholders (agency cost).

If the above reasons are the sole purpose of corporate governance, we can assume that it is not necessary in a family firm because shareholders and managers lead the company with the same goal which is as Zaff (2000) said: the transmission of the company to the next generation. It is observed that managers of companies will avoid corporate governance because their desire is to act and freely take any decision for the firm independently. This is one of the reasons managers and administrators always have problems. Managers don't give all the information that the administrators need to make a decision or to appreciate their propositions.

Nevertheless, corporate governance still has a reason to interest family firm's shareholders. As Wolfgang, Andreas and Heinz (2003) said, we think that to solve this problem of avoiding the corporate governance in the family firm, it would be better for managers and shareholders to understand corporate governance as a chance not as an obligation from the firm's perspective. So that the family firm can avoid mismanagement problems, thus they can transfer the firm to their descendant without the risk of bankruptcy. Owner-managers also understand that their family firms' survival depends on their ability to enter new markets and revitalize existing operations in order to create new businesses (Ward, 1987). 
In Cameroon, most of the family businesses are characterized by the concentration of capital in the hands of one person, with family members of the proprietor involved in the management of the company and low financing by bank loans. As noted Tchankan (2002), the family firm has characteristics that are unique because, unlike other companies, the significant presence of members who belong to the same family unduly influences his vision, his perception and values which determine its culture, its structure and function. Today, with increasingly greater competition, economic globalization and technological changes, family businesses are forced to adopt growth strategies. Given that growth requires additional funding and given the limited resources of the family business, it is therefore necessary to analyze the funding patterns of these family businesses.

In this paper, we will try to find answers to following questions:

- What are the financing options for the family firms in the Northern Cameroon?

- How is the composition of the Board of Director in the family firms of the Northern Cameroon?

- What are the links between the composition of the board of directors and financing choices of family businesses in the Northern Cameroon?

\section{Definition of the family firm}

Definitions of family business are varied (Catry and Buff, 1996). Several terms are being used to describe the family firm: family business, business in family hands, family-owned business, family firms, Family Corporation, etc. However, what is exactly a family business?

In the literature, we found three criteria to identify family firms: first, the fact that the control of capital is largely in the hands of one family, on the other hand, the fact that there is a strong interference of the family members in business management, and finally, the fact that family shareholders have a desire to transfer their business to the next generation. Several definitions have been identified by Allouche and Amman (1999) and summarized in table 1.

In summary, we retain the definition of Colot and Croquet (2005), which seems the most recent and most suitable to our context. For these authors, a family business is one in which members of one family have almost exclusively control of shares and management of the company in order to ensure its long-term preservation in the family patrimony.

\section{Financial choices of family firm's managers}

Several authors argue that owners of family businesses avoid external funding as that will reduce their influence in firm's decisions. Colot and Croquet (2005) believe that family businesses will issue an IPO as a last option, as this mode of financing may result in loss of control of the company, if the family does not participate in the operations. The separation of ownership and control leaves shareholders with little or no control over the actions of a company's managers (Berle and Means, 1932). They also insinuated that the participation of the manager in capital provision has a negative influence on the degree of indebtedness. In a business dominated by owner-manager, the board use to ratify any decisions taken.

Zaff (2000) stated that investors often refuse to invest their capital in companies not applying the principles of corporate governance. Caby and Hirigoyen (2001) refer to this as the dilemma confronting family business and bankers because of the frequent interrelationship of personal and professional asset. But in Cameroon, with the exception of an IPO, family businesses use alternative sources of funding. We can mention the contribution of the owner, reinvestment of profits, personal savings, donations and loans from relatives (Tchankam, 2002). In addition, several authors contradict themselves on ways of financing family businesses. Zurich (2005) states that the debt ratio of family firms is lower than non-family enterprises, while Colot and Croquet (2005) believe that family firms are more indebted than non-family firms. We believe that except the capital structure of the firm, there is another variable that is influencing its financing choice. For the case of this paper, the variable that has been chosen is the composition of the board of directors.

\section{Board of directors and financial choices}

Charreaux (2004) stressed that the composition and size of the board of directors have a significant impact on the firm's performance. Jensen and Meckling (1976) argued that if the manager is a significant shareholder in the company he runs, this has the effect of reducing such conflicts of interest between shareholders and managers; to the extent he may financially support the poor performance in case of mismanagement on his part. Abdelwahed (2003) added that a board of directors consisting of a large number of administrators can control, ratify or reject decisions made by managers. We note that the majority of research in the field of corporate governance holds the Board of Directors as a governing body. However, the board of directors is 
presented in many forms in the case of Cameroonian context, especially in the Northern Cameroon. Thus we can find, the Board of Directors, the family council, the general meeting of shareholders, the supervisory board, etc. Whatever the form of the governing body is, we are concerned by its composition.

\section{The presence of independent administrators in the BOD}

Recent researches confirm that outside directors (independent administrators) are important in monitoring managerial actions. However, only a limited number of studies focus directly on the issue of the Board's impact on shareholders' wealth.

Independent administrators are non-salaried and non-shareholders, unrelated to the managers, who can make decisions without being influenced. The Viénot report (1995) defines an independent director as a person absolutely devoid of any link of interest, direct or indirect contact with the company or its affiliates. The report adds that consequently, the independent director must not be:

- An employee, the president or CEO of the company or its affiliates, if he was an employee, director or chairman of the company or its affiliates, it must be stopped for at least three years;

- A major shareholder of the company or of its affiliates, related in any manner to a significant partner or its affiliates.

Boards should include Independent Directors in line with the regulatory framework or codes of governance. The responsibilities of the Independent Directors include contributing to strategy and monitoring managerial performance, as well as staffing the key audit, remuneration and nomination committees, and influencing the conduct of the Board (International Corporate Governance Network Principles).

Several researches tell us that independent directors make decisions for the interests of the company, and this without being influenced by the purpose of family members which is to keep the entire control of the company. For this reason, Fatma and Dominique (2005) showed that there is a positive relationship between the presence of independent directors and the leverage of the company. This means that independent directors, whose function is to secure the providers of resources, enable the company to increase its credibility and therefore its borrowing capacity. These same authors showed once again that there is a negative relationship between the presence of independent directors and the shareholders' weight. This implies that the goal of family shareholders, namely to retain almost exclusive control by avoiding external finance, is shaken. The presence of independent directors in the board of directors is a way to secure the funds provided by outside investors.

\section{High proportion of family members in the BOD}

In most family businesses, the governing body is composed mostly by family members. However, all family businesses are not controlled by shareholders' family members. In some cases, there may be agency problem. Family members involved in the BOD tend to reject any decision of external financing in order to prevent dilution of the capital. Friedman (1994) confirms this assertion by saying that risk aversion is enhanced by the willingness of transmission of the family business to the next generation. Other authors such as Gallo and Villaseca (1996) showed that family businesses have low debt to equity, that is to say a low level of debt due to the fear of bankruptcy or loss of control of the company. In addition, Poincelot (1999) reinforces the saying that debt is a variable manipulated by the leaders that control the firm. The ownership control or influence of the family in managing the business is a result of their intention to transfer the firm to the next generation. Ward (1982) also stressed that a family may experience a feeling of moral obligations towards other stakeholders or even considers their company as a way to make a positive contribution to the society. Colot and Croquet (2005) believe that increasing financial debt and indirectly the default risk of the firm may be perceived by shareholders as a kind of abandonment of a portion of their control in the hands of debt holders. The family business has some shareholding and managerial characteristics that might influence their funding decisions (Colot and Croquet, 2005).

\section{Data and Methodology}

This study has been conducted using the response of a survey which has been submitted to a sample of 120 family owned firms in the northern Cameroon. The firms have been sampled from the database provided by the Cameroonian chamber of Commerce and Tax service, in accordance with the family business definitions of Colot and Croquet (2005). Specifically, the family firms have been chosen in respect of the following three basic requirements: (i) a family has almost exclusively a control of shares and management on the company in order to ensure its long-term preservation in the family patrimony; (ii) the presence of, at least, one family member inside the managerial team and the shareholder base; (iii) the capital of the company should be totally owned by private individuals. We sent a letter to each firm, explaining the study and its objectives. Among the family firms that 
have answered, 100 fulfilled the requirements of the research. In the northern Cameroon, most of family businesses are very small and they do not feel the need to establish a formal board of directors, but they usually have a Sole Director.

Getting the answer from the questionnaire distributed to the managers of those companies, we have defined variables that follow:

\section{$>$ Financing choices (FIN)}

We have grouped financial choices in three main sources of funding:

- Self financing (AUTOFI): we have gathered here the personal contributions of shareholders, gifts and caregivers, reinvestment of profits, the incorporation of reserves, and any other source of funding that do not appeal to partners outside of the family ; internal financing sources limits their internationalization (Barry, 1975; Gallo \& vilaseca, 1996).

- Debt (DEBT): we mean debt suppliers, bank loans, annuity schemes, bonds, and any other funding source nature of borrowing which requires a repayment;

- Opening the capital (OC): this is essentially the sale of shares and the IPO. More family firm owners have come to realize that going public is essential for long-term growth and to survive (Pagano, Panetta \& Zingales, 1998).

\section{$>$ Corporate governance's variables (predictors)}

Regarding the composition of the board of directors, we also identified three variables:

- Family Membership Officer (FMO): FMO is whether the officer of the company belongs or not to the shareholders' family;

- The higher proportion of family members in the board of directors (FAM): There is a dominance of the BOD if a majority of members present in the BOD belongs to the same family as the shareholders;

- The presence of independent directors (INDEP): It is about the presence of people who have no connection with the family's shareholders, who are able to hang decisions without being influenced by either the executive or the family shareholders (they are among other banks, institutional investors, representatives of financial markets, financial experts and accountants, etc.).

\section{Econometric Model}

The impact of the composition of the board of directors on the likelihood of a company choosing a particular financing type is estimated with a logistic regression. The estimation of this model involves a dependent binary variable that will have a value of one for those cases in which the firm uses a particular financing type and zero otherwise. The following regression will be used to understand the link between corporate governance and financing choices in family business.

$$
\text { FIN }=\alpha_{0}+\alpha_{1} \text { FMO }+\alpha_{2} \text { FAM }+\alpha_{3} \text { INDEP }+\xi
$$

From the main pattern, we can write three sub-patterns that follow:

$$
\begin{aligned}
& \text { AUTO }=\beta_{0}+\beta_{1} \text { FMO }+\beta_{2} \text { FAM }+\beta_{3} \text { INDEP }+\delta \\
& \text { DEBT }=\gamma_{0}+\gamma_{1} \text { FMO }+\gamma_{2} \text { FAM }+\gamma_{3} \text { INDEP }+\psi \\
& \text { OC }=\mu_{0}+\mu_{1} \text { FMO }+\mu_{2} \text { FAM }+\mu_{3} \text { INDEP }+\pi
\end{aligned}
$$

\section{Empirical results}

\section{- Corporate governance and self financing choice in family firms}

According to the results in Table 2, we found that there is a higher correlation $(\mathrm{B}=4.906)$ between self financing choice and the fact that the manager of the company is a member of the shareholders' family. Even the high value of Wald (40.536) confirms that the family managers prefer self financing choices to any other financing choices. This result confirms what we said before about the behavior of most of family managers who avoid external fund due to the fact that they want to keep exclusively the control of the business they run.

\section{- Corporate governance and Debt in family firms}

The results in Table 3 show that when the manager is a member of a shareholders' family, the company avoid debt $(\mathrm{B}=-1.471)$. We found also the same behavior of avoiding debts when the board is dominated by the 
members of the shareholders' family $(B=-1.066)$. But there is a positive relationship between the presence of independent administrators in the board and debt level in the family firms. This can be explained by the knowledge of independent administrators who try their best to increase the performance of the firm by making the best financing decision (static trade-off) for the company. As Myers (2001) said the static trade-off theory, focuses on the benefits and costs of issuing debt, predicts that an optimal target financial debt ratio exists, which maximizes the value of the firm. The optimal point can be attained when the marginal value of the benefits associated with debt issues exactly offsets the increase in the present value of the costs associated with issuing more debt.

\section{- Corporate governance, Opening Capital and IPO in family firms}

The most significant results are the dominance of the board by the member of shareholders' family and the presence of the independent administrators. We found in Table 4 a negative relation $(B=-1.932)$ between the dominance of the board by the family members and the opening of the firm's capital. The interpretation of these results on opening capital and corporate governance in family firms is that, in order for families to keep control, they prefer to finance new investments either by internal finance - and hence pay themselves less dividends in order to leave more cash flows in the firm - or through debt rather than new equity.

In addition, the results in the table show that the family firms are willing to source for capital only when the independent administrators are present in the board of directors $(B=5.884)$. It is already known that the Initial Public Offering maximizes the performance of the firms, so we understand why the independent administrators are willing to use it with the purpose of increasing the performance by the way to reduce asymmetric information and agency cost problems. As Ward (1997) said, for the family-owned business, good governance makes all the difference. Family firms with effective governance practices are more likely to do strategic planning and to do succession planning. On average, they grow faster and live longer.

\section{Conclusion}

In this paper, we have empirically investigated the relationship between corporate governance and financing choices for the family firms in the northern Cameroon. Although the research is limited by the small number of companies, our study suggests the following findings:

i) There is a significant and positive relationship between the fact that the manager is a member of shareholders' family and self financing choices;

ii) Family firms with a dominant presence of family members' in the corporate governance structures avoid as much as possible external funding, and when it has to be used, debt is preferable to new equity or IPO;

iii) Family firms with independent directors are willing to use external financing choices even new equities and IPO if it is in the best interest of the company. Independent administrators are expected to monitor management's self-interest more effectively than family members.

Our results confirm the studies of the financial behavior of owner-managers of privately held firms, due to control tendencies, often follow the principles of the pecking order i.e. they have a propensity to finance their operations in a hierarchical fashion, first using internally available funds, followed by debt, and finally external equity (Petitt and Singer, 1985).

In order to confirm the results founded in this study, we suggest enlarging the number of firms in our sample and to include more variables in the model, so that we can have clear details of the links between corporate governance mechanism and family firm's financing choices.

\section{References}

Abdelwahed O. (2003). Gouvernance et performance des entreprises tunisiennes, RFG, vol. 29, No142, Jan-Fev 2003.

Allouche J. et Amann B. (1998). La confiance : une explication des performances des entreprises familiales, Economies et sociétés, sciences de gestion, série SG, no 8-9/1998.

Allouche J. et Amman B. (1997). Le retour triomphant du capitalisme familial?, l'Expansion Management Review, juin 1997.

Allouche J. et Amman B. (1999). L'entreprise familiale: un état de l'art, Revue Finance-Contrôle- Stratégie.

André de Serres (2004). Une analyse comparative des stratégies d'intervention en matière de gouvernance éthique et de responsabilité sociale des entreprises aux Etats Unis, au Royaume Uni et en France, Revue des Sciences de Gestion, Direction et Gestion, no 211-212, RSE. 
Barry, B. (1975). The development of organization structure in the family firm, Journal of General Management, Autumn, 42-60.

Basly S. (2004). Propriété, décision et stratégie de l'entreprise familiale: une analyse théorique, ICS Paris et CREFF, Université de Bordeaux IV.

Berle A. and Means G. (1932). The Modern Corporation and Private Property. New York: Macmillan.

Caby J. et Hirigoyen G. (2001). La gestion de l'entreprise familiale, Paris, Economisa.

Catry B. et Buff A. (1996). Le gouvernement de l'entreprise familiale, Public-Union Edition, Université de Montesquieu.

Chapas B. (2004). Evolution de la rémunération des dirigeants et transformation de leur légitimité, Revue des Sciences de Gestion, Direction et Gestion, no 211-212, RSE.

Charreaux Gerard J. (2004). Corporate Governance Theories: from Micro Theories to National Systems Theories, Université de Bourgogne - LEG/FARGO.

Chatelin C. et Trébucq S. (2003). Stabilité et évolution du cadre conceptuel en gouvernance d'entreprise: un essai de synthèse, communication pour les $9 \mathrm{e}$ journées d'histoire de la comptabilité et du management, Crefige-Université Paris-Dauphine.

Colot O. et Croquet M. (2002). Les variables de propriété et de gestion ont-elles une influence sur la structure d'endettement des PME?, centre de recherche Warocqué, Université de Mont Hainaut.

Colot O. et Croquet M. (2005). Les entreprises familiales sont-elles plus ou moins endettées que les entreprises non familiales?, centre de recherche Warocqué, Faculté Warocqué/Université de Mont Hainaut.

Dessertine P. (2000). Le nouveau marché: rencontre de l'entreprise familiale et de la logique boursière, cahier de recherche, no 2000-04, CREF.

Fama, E. F., Jensen M. C. (1983). Separation of ownership and control, Journal of Law and Economics 26, 301-325.

Fatma T. et Dufour D. (2005). Une analyse de la présence d'administrateurs indépendants au sein du conseil d'administration: contrôle ou conseil, Centre de Recherche en Ingénierie Financière et Finances publiques (CRIFP). Université de Nice-Sophia Antipolis.

Gallo Miguel A. \& Vilaseca A. (1996). Finance in Family Business, Family Business Review, Vol. 9, No. 4, 387-401.

Ginglinger E. (2002). L’actionnariat comme contrôleur, Revue Française de Gestion, $N^{\circ} 141$.

Hirigoyen G. (1982). Le comportement financier des moyennes entreprises industrielles familiales, Banque, no 417.

Hirigoyen G. (1997). Le gouvernement des entreprises, Economisa.

Hirigoyen G. et Poulain-Rhem T. (1999). La politique de stock-options des entreprises familiales cotées : quelques résultats empiriques, cahier de recherche, no 1999-03, CREF.

Jensen et Meckling (1976). Theory of the firm: Managerial behavior, agency costs, and ownership structure, Journal of financial economics, 3:305-360.

Jonathan P. R. (2005). Marché de la finance informelle en Afrique, confiance explicitée et non transferabilité des logiques : Essai de conceptualisation à travers le cas des micro-entrepreneurs, Actes du séminaire international, REGE.

Juvin H. (2005). La gouvernance, piège pour les organisations ; Expansion Management Review, ${ }^{\circ} 116$.

Khanchel I. (2005). Changement stratégique et gouvernance, Revue des Sciences de Gestion, Direction et Gestion, no 213-Stratégie.

Laurance G. (1998). Choix entre conseil d'administration et conseil de surveillance, Finance-Contrôle-Stratégie, vol.1, no4.

Laurance G. et Schatt A. (2000). Quelles sont les caractéristiques optimales du conseil d'administration ?, Revue Financier, $\mathrm{N}^{\circ} 127$.

Laurance G. et Schatt A. (2005). Les caractéristiques et fonctionnement du conseil d'administration français. Un état des lieux, Revue Française de Gestion, vol.31, $\mathrm{N}^{\circ} 158$. 
Le BARS B. (2004). Management et financement de la société anonyme de droit OHADA, Cahier de Droit de l'entreprise, JCP, No5.

Myers S.C., 2000, Capital Structure, Journal of Economic Perspectives 15 (2). 81-102

Oman C., Fries S. et Buiter W. (2003). Gouvernance d'entreprise dans les pays en développement, en transition et les économies émergentes, Centre de développement de l’OCDE, cahier de politique économique, $\mathrm{n}^{\circ} 23$.

Pagano, Panetta, and Zingales (1998). Why do Companies go Public? An Empirical Analysis. Journal of Finance, February 1998.

Pettit, R. \& Singer R. (1985). Small business finance: A research agenda, Financial Management, Autumn, 47-60.

Pichard Stamford J-P. (2000). Légitimité et enracinement du dirigeant par le réseau des administrateurs, cahier de recherche, $n^{\circ}$ 2000-04, CREF.

Poulain-Rhem T. (2006). La politique de financement des entreprises patrimoniales et familiales cotées : un test de la théorie du free cash flow, la Revue Financier, $n^{\circ} 153$.

Roth F. (2000). Gouvernement des entreprises et stratégie du dirigeant: une étude clinique dans le secteur de l'assurance, Finance Contrôle Stratégie, vol.3, N4, Décembre 2000.

Straer D. (2003). Les entreprises familiales sont-elles inefficaces ?, Mémoire de DEA, CREST-INSEE.

Tchankam J-P. (2002). L'entreprise familiale au Cameroun, cahier de recherche, n²000-05, CREF.

Vienot Report. (1995). Corporate Governance - Clifford Chance.

Wanda R. (2001). Structure financière et performance des entreprises dans un contexte sans marché financier : le cas du Cameroun, FSEG, Université de Yaoundé II, Cameroun.

Ward, J. L. (1987). Keeping the family business healthy: How to plan for continuous growth, profitability and family leadership, San Francisco: Jossey Bass.

Ward John L. (1997). Growing the family business: special challenges and best practices, Family Business Review, Vol. 10 No.4, pp. 323-337.

Wolfgang D., Andreas S. and Heinz Z. (2003). Corporate Governance and Expected Stock Returns: Evidence from Germany, University of Basel - Center for Economic Science, Department of Finance; ECGI - Finance Working Paper No. 11

Yuan Ding. (2000). Les entreprises familiales chinoises, cahier de recherche, no 2000-02, CREF.

Zafft R. (2000). Gouvernement d'entreprise: une affaire de famille, Direction des affaires financières, fiscales et des entreprises de l'OCDE.

Zurich. (2005). Les valeurs de leur dirigeant sont déterminantes pour les entreprises familiales, communiqué de presse du 06 juillet 2005. 
Table 1. Definitions of the Family Firm

\begin{tabular}{|l|l|l|}
\hline 1- One criteria definition & Authors & Content \\
\hline \multirow{3}{*}{ Property } & $\begin{array}{l}\text { Barnes L. B. Hershon S. A. (1976); Alcon P.B. (1982); } \\
\text { Lansberg I., Perrow S. et Rogolsky S. (1988). }\end{array}$ & $\begin{array}{l}\text { The company is owned by an individual or } \\
\text { members of one family. }\end{array}$ \\
\cline { 2 - 4 } Control & $\begin{array}{l}\text { Barry B. (1975); Beckhard R., Dyer W. (1983); } \\
\text { Keppner E. (1983); Handler W. C. (1989). }\end{array}$ & $\begin{array}{l}\text { The company is controlled by a family more or } \\
\text { less enlarged. The board of directors is the focal } \\
\text { point of this control. }\end{array}$ \\
\hline 2- Multi-citerions definition & $\begin{array}{l}\text { Davis J. A. et Taiguri R. (1982); Davis J. et Pratt } \\
\text { (1985); Rosenblatt P., Anderson R., Jonhson (1985); } \\
\text { Dyer W. G. (1986); Stern M. H. (1986); Hollander B. } \\
\text { et Elman N. (1988); Aronoff C. E. et Ward J. (1990); } \\
\text { Astrachan J. et Kolenko T. (1994); Cromie S. et } \\
\text { Property and control }\end{array}$ & $\begin{array}{l}\text { The company is owned by an individual or a } \\
\text { less extended (with varying intensity in the } \\
\text { control). }\end{array}$ \\
\hline \multirow{2}{*}{$\begin{array}{l}\text { Property, transmission and control } \\
\text { Oonnership and domination of the (1995). } \\
\text { family, the name of the company }\end{array}$} & Churchill N., Hatten K. J. (1987), Ward J. (1987) & $\begin{array}{l}\text { The transfer of the business to another } \\
\text { generation has been (or will be) done. The new } \\
\text { generation must keep the control of the firm. }\end{array}$ \\
\hline
\end{tabular}

Source: José Allouche et Bruno Amman (1999), “l'entreprise familiale : un état de l'art', Revue Finance-

Contrôle- Stratégie, P.12

Table 2. Corporate Governance and Self Financing Choice

\begin{tabular}{|l|l|l|l|l|l|l|}
\hline Variables & B & S.E. & Wald & df & Sig. & $\operatorname{Exp(B)}$ \\
\hline FOM & 4.906 & .771 & 40.536 & 1 & .000 & 135.100 \\
\hline FAM & .078 & .749 & .011 & 1 & .917 & 1.081 \\
\hline INDEP & -.004 & .846 & .000 & 1 & .996 & .996 \\
\hline Constant & -7.920 & 2.136 & 13.754 & 1 & .000 & .000 \\
\hline
\end{tabular}

Table 3. Corporate Governance and Debt

\begin{tabular}{|l|l|l|l|l|l|l|}
\hline Variables & B & S.E. & Wald & df & Sig. & $\operatorname{Exp(B)}$ \\
\hline FOM & -1.471 & .494 & 8.885 & 1 & .003 & .230 \\
\hline FAM & -1.066 & .473 & 5.076 & 1 & .024 & .344 \\
\hline INDEP & .770 & .484 & 2.533 & 1 & .111 & 2.160 \\
\hline Constant & 2.004 & 1.177 & 2.900 & 1 & .089 & 7.418 \\
\hline
\end{tabular}

Table 4. Corporate Governance and Capital Opening

\begin{tabular}{|l|l|l|l|l|l|l|}
\hline Variables & B & S.E. & Wald & df & Sig. & $\operatorname{Exp}(\mathrm{B})$ \\
\hline FOM & .251 & .836 & .090 & 1 & .764 & 1.285 \\
\hline FAM & -1.932 & 1.107 & 3.047 & 1 & .081 & .145 \\
\hline INDEP & 5.884 & 1.168 & 25.364 & 1 & .000 & 359.301 \\
\hline Constant & -6.351 & 1.948 & 10.629 & 1 & .001 & .002 \\
\hline
\end{tabular}

